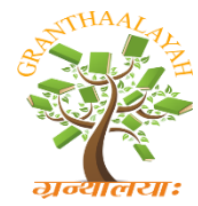

INTERNATIONAL JOURNAL OF RESEARCH GRANTHAALAYAH A knowledge Repository

Management

\title{
A STUDY ON EMPLOYER BRANDING WITH SPECIAL REFERENCE TO HIROTEC INDIA PRIVATE LIMITED
}

\author{
Karthika.M*1, Dr.V.Latha ${ }^{2}$ \\ ${ }^{*}$ Assistant Professor, UG Management Sciences, Sri Ramakrishna College of Arts and Science \\ (Formerly SNR Sons College, Coimbatore), India \\ ${ }^{2}$ Dean, School of Management, Sri Ramakrishna College of Arts and Science (Formerly SNR \\ Sons College, Coimbatore), India
}

DOI: https://doi.org/10.29121/granthaalayah.v5.i6.2017.2070

\begin{abstract}
Employer branding is the most recent and current trend in every organization today. Due to lack of employer branding organizations are facing lots of problems in retaining talented workforce especially in industries. The primary objective is to study on employer branding with special reference to Hirotec India Private Limited, Coimbatore. This study would help the Hirotec India Private Limited professionals to focus on the need for the development and exploration of effective Employer-Branding techniques and strategies/ interventions. In the present research, deductive research method has been followed. The field survey method was employed to collect the primary data from 219 respondents through a well framed questionnaire. The result indicated that the development value in employer branding influenced the employee's turnover intention. The resultant framework is useful in providing a better understanding on how to improve an effective human resource management from an administrative perspective. The findings would make obtainable for the organizations' management to improve their strategic planning to preserve their valuable employees, thus, building the human assets for the organization.
\end{abstract}

Keywords: Employer Branding; Quality of Work Life; Work Environment; Level of Satisfaction; Organizational Management Style.

Cite This Article: Karthika.M, and Dr.V.Latha. (2017). "A STUDY ON EMPLOYER BRANDING WITH SPECIAL REFERENCE TO HIROTEC INDIA PRIVATE LIMITED.” International Journal of Research - Granthaalayah, 5(6), 527-543. https://doi.org/10.29121/granthaalayah.v5.i6.2017.2070.

\section{Introduction}

Employer branding is the most recent and current trend in every organization today. Due to lack of employer branding organizations are facing lots of problems in retaining talented workforce especially in industries. This research is focused on finding out the attractiveness dimensions of 
employer branding of Hirotec India Private Limited imparting technical education. For a long time, branding has merely been concerned with endearing customers to a product/service and sustaining brand loyalty. It was taken for granted that a strong brand requires efficient employees who work seamlessly to actualize the brand's vision. The issue for employers thus becomes, how to strategically attract and engage employees who believe in the goals and aspirations of the organization and are efficient enough to bring their resources into ensuring the success of the brand. In order to understand the employer branding stages and processes in Hirotec India Private Limited, this study will be more helpful to the management as well as the concern HR team.

\subsection{Objectives of the Study}

1) To study on employer branding with special reference to Hirotec India Private Limited, Coimbatore

2) To identify the factors influencing the employer branding in Hirotec India Private Limited.

3) To know about the work environment and organizational management style in Hirotec India Private Limited.

4) To know the level of satisfaction of the employees on quality of work life (qwl) in Hirotec India Private Limited.

5) To identify the constraints faced by the employees in Hirotec India Private Limited.

6) To give feasible solutions based on the findings analyzed and interpreted.

\subsection{Need of the Study}

1) This study would help the Hirotec India Private Limited professionals to focus on the need for the development and exploration of effective Employer-Branding techniques and strategies/ interventions.

2) The awareness towards effective Employer-Branding would be enhanced among professionals and the policy-makers.

\subsection{Scope of the Study}

The main scopes of the study are as follows,

1) The findings would shed light on how to cut expenses of Hirotec India Private Limited by analyzing employee branding related expenditures.

2) Exploration of employer branding as a long-term strategy of effective hiring (recruitment and selection)

3) The study will be the provision of an insight to future researchers and mangers, concerning the role of employer image in recruiting.

4) The provision of insight and orientation to recruiters on the importance of efficient and well-organized recruitment process.

5) This is an effective solution to the problem of talent retention within an organization. This is due to the fact that the employer branding is the only available solution to the corporate recruiters in maintaining the flow of talent within some organization. 
6) Last but not the least providing the empirical scenario of employer branding in Hirotec India Private Limited.

\section{Research Methodology}

The present research focuses on Employer Branding in Hirotec India Private Limited. The philosophy that is used in this research is realism. For this the researcher uses acceptable knowledge in the field of factors influencing the employer branding,work environment, organizational management style, quality of work life and constraints faced by the employees to understand the Employer branding in Hirotec India Private Limited. The researcher collects and analyses data using acceptable knowledge for the purpose of answering the research question, so the research is more inclined towards realism.

\subsection{Research Approach}

In the present research, deductive research method has been followed. A set of hypotheses has been formulated related to objectives of employer branding that need to be confirmed or rejected during the research process.

\subsection{Research Strategy}

The investigator has adopted the survey method in this study. In this method, collecting and analyzing the data are the basic steps. The survey method gathers data from a relatively large number of cases at a particular time. It is not concerned with characteristics of the individual, but is concerned with the generalized statistics that results when data are abstracted from a number of individual cases. The information is collected through a detailed questionnaire. It provides factual information about the employer branding in the area of study. It gathers data from relatively large number of cases at a particular time and focuses attention upon the needs that would remain unnoticed.

\subsection{Data Collection - Primary Data}

The major source of the data used to carry out the analysis is primary data. The field survey method was employed to collect the primary data from 219 respondents through a well framed questionnaire. The respondents with varying background in Employees based on their demographic aspects like Age, Gender, Marital Status, Level of Education, Designation, Monthly Income, Department, Shift timing of working and experience were selected for the study. The second section consisted of questions related to employer branding based on the objectives designed. In order to answer the research questions on the factors related to the employer branding factors, the respondents were guided by a 5 point Likert scale (Strongly agree to strongly disagree, High preference to No preference). Data which has already gone through the process of analysis or were used by someone else earlier is refers to secondary data. 


\subsection{Research Design}

Since Employer Branding is an extensive term a descriptive type of research was undertaken. The research aim was to study on Employer branding in Hirotec India Private Limited.Initial literature review was carried out, wherein various research papers related to employer branding published were gone through. The objectives were set. The targeted population was Employees in Hirotec India private Limited. A questionnaire was compiled taking into account the various aspects of Employer Branding, its meaning or interpretations. A structured form of questionnaire having all close ended questions was prepared.

Table 1: Distribution of Samples based on Variables

\begin{tabular}{|c|c|c|c|c|c|}
\hline S.NO & Category & Subgroups & Number & $\%$ & Total \\
\hline \multirow{3}{*}{1.} & \multirow[t]{3}{*}{ Age } & $<25$ years & 56 & 25.6 & \multirow[t]{3}{*}{219} \\
\hline & & $25-35$ years & 149 & 68 & \\
\hline & & $35-45$ years & 14 & 6.4 & \\
\hline \multirow[b]{2}{*}{2.} & \multirow[t]{2}{*}{ Gender } & Male & 207 & 94.5 & \multirow[t]{2}{*}{219} \\
\hline & & Female & 12 & 5.5 & \\
\hline \multirow[b]{2}{*}{3.} & \multirow[t]{2}{*}{ Marital Status } & Married & 92 & 42 & \multirow[t]{2}{*}{219} \\
\hline & & Unmarried & 127 & 58 & \\
\hline \multirow[t]{4}{*}{4.} & \multirow{4}{*}{$\begin{array}{l}\text { Educational } \\
\text { Qualification }\end{array}$} & School Level & 5 & 2.3 & \multirow[t]{4}{*}{219} \\
\hline & & Diploma & 71 & 32.4 & \\
\hline & & Under Graduate & 127 & 58 & \\
\hline & & Post Graduate & 16 & 7.3 & \\
\hline \multirow[t]{4}{*}{5.} & \multirow{4}{*}{$\begin{array}{l}\text { Educational } \\
\text { Qualification of } \\
\text { father }\end{array}$} & Below $10^{\text {th }}$ & 66 & $30 \%$ & \multirow[t]{4}{*}{219} \\
\hline & & UG & 71 & $32.3 \%$ & \\
\hline & & PG & 23 & $10.5 \%$ & \\
\hline & & Professional & 60 & $27.3 \%$ & \\
\hline \multirow[t]{6}{*}{6.} & \multirow[t]{6}{*}{ Designation } & Worker & 102 & 46.6 & \multirow[t]{6}{*}{219} \\
\hline & & Manager & 17 & 7.8 & \\
\hline & & Supervisor & 34 & 15.5 & \\
\hline & & Office Staff & 60 & 27.4 & \\
\hline & & Engineer & 5 & 2.3 & \\
\hline & & Team Lead & 1 & 0.5 & \\
\hline \multirow[t]{4}{*}{7.} & \multirow[t]{4}{*}{ Monthly Income } & Below Rs.5000 & 4 & 1.8 & \multirow[t]{4}{*}{219} \\
\hline & & Rs. $5000-$ Rs. 15000 & 7 & 3.2 & \\
\hline & & $\begin{array}{l}\text { Rs.15000- } \\
\text { Rs.20000 }\end{array}$ & 18 & 8.2 & \\
\hline & & Above Rs.20000 & 190 & 86.8 & \\
\hline \multirow[t]{6}{*}{6.} & \multirow[t]{6}{*}{ Department } & Production & 176 & 80.4 & \multirow[t]{6}{*}{219} \\
\hline & & Marketing & 15 & 6.8 & \\
\hline & & Finance & 9 & 4.1 & \\
\hline & & Human Resource & 6 & 2.7 & \\
\hline & & Design & 11 & 5.0 & \\
\hline & & Database & 2 & 0.9 & \\
\hline
\end{tabular}




\begin{tabular}{|l|l|l|l|l|l|}
\hline 7. & Shift Timings & $8 \mathrm{am}-5 \mathrm{pm}$ & 14 & 6.4 & \multirow{2}{*}{219} \\
\cline { 3 - 5 } & & $9 \mathrm{am}-6 \mathrm{pm}$ & 203 & 92.7 & \\
\cline { 3 - 5 } & & $\begin{array}{l}3.30 \mathrm{pm}-11.59 \\
\mathrm{pm}\end{array}$ & 2 & 0.9 & \\
\hline $\mathbf{8 .}$ & Experience & Below 1 year & 35 & 16 & \multirow{2}{*}{219} \\
\cline { 3 - 5 } & & $1-5$ years & 125 & 57.1 & \\
\cline { 3 - 5 } & $5-10$ years & 43 & 19.6 & \\
\cline { 3 - 5 } & & $10-15$ years & 16 & 7.3 & \\
\hline
\end{tabular}

\section{Testing the Hypotheses}

Hypothesis 1: There is no significant association between age and compensation

Table 2: CrossTabulation and Chi-Square Result of Age and Compensation

\begin{tabular}{|c|c|c|c|c|c|c|}
\hline \multirow{2}{*}{ AGE (in years) } & \multicolumn{6}{|c|}{ COMPENSATION } \\
\hline & $\begin{array}{l}\text { Strongly } \\
\text { Agree }\end{array}$ & Agree & Neutral & Disagree & $\begin{array}{l}\text { Strongly } \\
\text { Disagree }\end{array}$ & TOTAL \\
\hline Below 25 years & 4 & 33 & 10 & 8 & 1 & 56 \\
\hline $25-35$ years & 5 & 79 & 54 & 9 & 2 & 149 \\
\hline $35-45$ years & 0 & 10 & 3 & 1 & 0 & 14 \\
\hline TOTAL & 9 & 122 & 67 & 18 & 3 & 219 \\
\hline \multicolumn{7}{|c|}{ CHI SQUARE TEST RESULT } \\
\hline \multirow{2}{*}{\multicolumn{4}{|c|}{ CALCULATED VALUE }} & \multicolumn{2}{|c|}{ TABLE VALUE } & D.F \\
\hline & & & & \multicolumn{2}{|c|}{15.507} & 8 \\
\hline
\end{tabular}

From the table 2, the calculated value 11.512 is less than the table value 15.507 at the level of $5 \%$ significance. Hence the null hypothesis is accepted. Thus it can be inferred that there is no significant association between age and compensation.

Hypothesis 2: There is no significant association between gender and superior relationship

Table 3: CrossTabulation and Chi-Square Result of Gender and Superior Relaionship

\begin{tabular}{|l|l|l|l|l|l|l|}
\hline \multirow{2}{*}{ GENDER } & \multicolumn{3}{l}{ SUPERIOR RELATIONSHIP } \\
\cline { 2 - 7 } & $\begin{array}{l}\text { Strongly } \\
\text { Agree }\end{array}$ & Agree & Neutral & Disagree & $\begin{array}{l}\text { Strongly } \\
\text { Disagree }\end{array}$ & TOTAL \\
\hline Male & 31 & 116 & 44 & 14 & 2 & 207 \\
\hline Female & 0 & 9 & 3 & 0 & 0 & 12 \\
\hline TOTAL & 31 & 125 & 47 & 14 & 2 & 219 \\
\hline CHI SQUARE TEST RESULT & \multicolumn{7}{l|}{ TABLE VALUE } & D.F \\
\hline CALCULATED VALUE & 9.488 & 4 \\
\hline 3.513
\end{tabular}

From the table 3, the calculated value 3.513 is less than the table value 9.488 at the level of $5 \%$ significance. Hence the null hypothesis is accepted. Thus it can be inferred that there is no significant association between gender and relationship. 
Hypothesis 3: There is no significant association between marital status and Personnel development

Table 4: CrossTabulation and Chi-Square Result of marital status and Personnel development

\begin{tabular}{|c|c|c|c|c|c|c|}
\hline \multirow[b]{2}{*}{$\begin{array}{l}\text { MARITAL } \\
\text { STATUS }\end{array}$} & \multicolumn{6}{|c|}{ PERSONNEL DEVELOPMENT } \\
\hline & $\begin{array}{l}\text { Strongly } \\
\text { Agree }\end{array}$ & Agree & Neutral & Disagree & $\begin{array}{l}\text { Strongly } \\
\text { Disagree }\end{array}$ & TOTAL \\
\hline Married & 10 & 64 & 16 & 1 & 1 & 92 \\
\hline Unmarried & 26 & 84 & 16 & 1 & 0 & 127 \\
\hline TOTAL & 36 & 148 & 32 & 2 & 1 & 219 \\
\hline \multicolumn{7}{|c|}{ CHI SQUARE TEST RESULT } \\
\hline \multicolumn{4}{|c|}{ CALCULATED VALUE } & \multicolumn{2}{|c|}{ TABLE VALUE } & D.F \\
\hline \multicolumn{4}{|c|}{5.357} & \multicolumn{2}{|l|}{9.488} & 4 \\
\hline
\end{tabular}

From the table 4, the calculated value 5.357 is less than the table value 9.488 at the level of $5 \%$ significance. Hence the null hypothesis is accepted. Thus it can be inferred that there is no significant association between marital status and personnel development.

Hypothesis 4: There is no significant association between educational qualification and growth \& Development

Table 5: CrossTabulation and Chi-Square Result of educational qualification and growth \&

Development

\begin{tabular}{|l|l|l|l|l|l|l|}
\hline \multirow{2}{*}{$\begin{array}{l}\text { EDUCATIONAL } \\
\text { QUALIFICATION }\end{array}$} & \multicolumn{6}{l}{ GROWTH \& DEVELOPMENT } \\
\cline { 2 - 8 } & $\begin{array}{l}\text { Strongly } \\
\text { Agree }\end{array}$ & Agree & Neutral & Disagree & $\begin{array}{l}\text { Strongly } \\
\text { Disagree }\end{array}$ & TOTAL \\
\hline School Level & 2 & 3 & 0 & 0 & 0 & 5 \\
\hline Diploma & 10 & 52 & 5 & 2 & 2 & 71 \\
\hline Under Graduate & 29 & 66 & 27 & 5 & 0 & 127 \\
\hline Post Graduate & 3 & 8 & 1 & 3 & 1 & 16 \\
\hline TOTAL & 44 & 129 & 33 & 10 & 3 & 219 \\
\hline CHI SQUARE TEST RESULT \\
\hline CALCULATED VALUE
\end{tabular}

From the table 5, the calculated value 27.866 is greater than the table value 21.026 at the level of $5 \%$ significance. Hence the null hypothesis is rejected. Thus it can be inferred that there is a significant association between educational qualification and growth \& development

Hypothesis 5: There is no significant association between present designation and job security 
Table 6: CrossTabulation and Chi-Square Result of present designation and job security

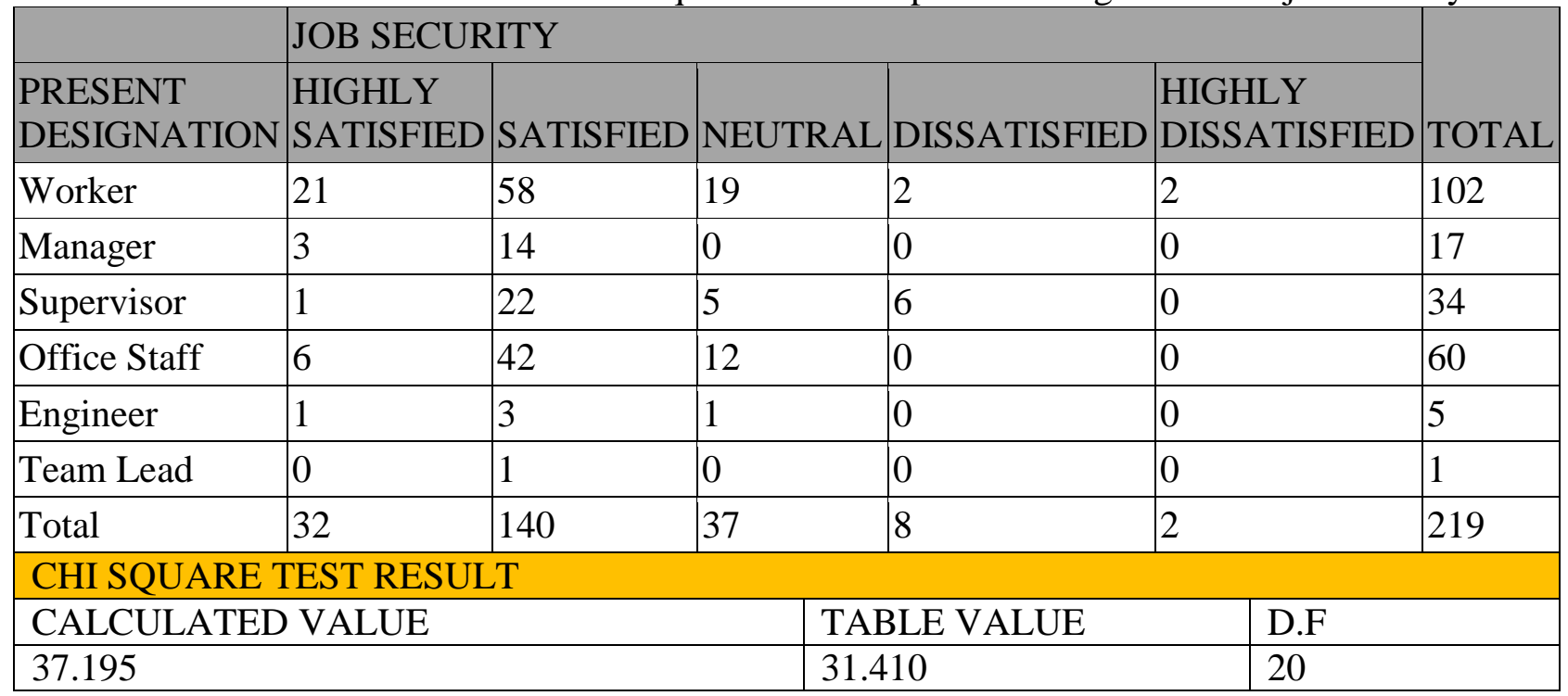

From the table 6 , the calculated value 37.195 is greater than the table value 31.410 at the level of $5 \%$ significance. Hence the null hypothesis is rejected. Thus it can be inferred that there is a significant association between present designation and job security.

Hypothesis 6: There is no significant association between monthly income and rate of pay

Table 7: CrossTabulation and Chi-Square Result of monthly income and rate of pay

\begin{tabular}{|l|l|l|l|l|l|}
\hline \multicolumn{5}{|c|}{ RATE OF PAY } & Noult \\
\hline Monthly Income & Highly satisfied & Satisfied & Neutral & Dissatied & Total \\
\hline Less than Rs 5000 & 0 & 0 & 2 & 0 & 2 \\
\hline Rs5000-15000 & 0 & 7 & 0 & 0 & 0 \\
\hline Rs15000-20000 & 8 & 8 & 2 & 0 & 0 \\
\hline Above 20000 & 5 & 88 & 74 & 22 & 1 \\
\hline Total & 13 & 103 & 78 & 22 & 3 \\
\hline CHI SQUARE TEST RESULT & TABLE VALUE & D.F & \\
\hline CALCULATED VALUE & 21.026 & 12 & \\
\hline 135.00 &
\end{tabular}

From the table 7, the calculated value 135.00 is greater than the table value 21.026 at the level of $5 \%$ significance. Hence the null hypothesis is rejected. Thus it can be inferred that there is a significant association between monthly income and rate of pay.

Hypothesis 7: There is no significant association between department and work group functioning 
Table 8: CrossTabulation and Chi-Square Result of department and work group functioning

\begin{tabular}{|c|c|c|c|c|c|c|}
\hline \multirow[b]{2}{*}{ DEPARTMENT } & \multicolumn{5}{|c|}{ WORK GROUP FUNCTIONING } & \multirow[b]{2}{*}{ Total } \\
\hline & \begin{tabular}{|l} 
Highly \\
Satisfied
\end{tabular} & Satisfied & Neutral & Dissatisfied & $\begin{array}{l}\text { Highly } \\
\text { Dissatisfied }\end{array}$ & \\
\hline Production & 11 & 107 & 54 & 4 & 176 & 11 \\
\hline Marketing & 3 & 8 & 4 & 0 & 15 & 3 \\
\hline Finance & 0 & 6 & 3 & 0 & 9 & 0 \\
\hline Human resource & 0 & 5 & 1 & 0 & 6 & 0 \\
\hline Total & 1 & 5 & 5 & 0 & 11 & 1 \\
\hline \multicolumn{7}{|c|}{ CHI SQUARE TEST RESULT } \\
\hline \multicolumn{3}{|c|}{ CALCULATED VALUE } & \multicolumn{3}{|c|}{ TABLE VALUE } & D.F \\
\hline \multicolumn{3}{|c|}{29.045} & \multicolumn{3}{|c|}{24.996} & 15 \\
\hline
\end{tabular}

From the table 8, the calculated value 29.045 is greater than the table value 24.996 at the level of $5 \%$ significance. Hence the null hypothesis is rejected. Thus it can be inferred that there is a significant association between department and work group functioning.

Hypothesis 8: There is no significant association between shift timings and job satisfaction

Table 9: CrossTabulation and Chi-Square Result of department and work group functioning

\begin{tabular}{|c|c|c|c|c|c|c|}
\hline \multirow[b]{2}{*}{ Shift Timings } & \multicolumn{5}{|l|}{ Job Satisfaction } & \multirow[b]{2}{*}{ Total } \\
\hline & Strongly Agree & Agree & Not Sure & Disagree & $\begin{array}{l}\text { Strongly } \\
\text { Disagree }\end{array}$ & \\
\hline $8 \mathrm{am}-5 \mathrm{pm}$ & 0 & 13 & 0 & 1 & 0 & 14 \\
\hline $9 \mathrm{am}-6 \mathrm{pm}$ & 22 & 142 & 32 & 4 & 3 & 203 \\
\hline $3.30 \mathrm{pm}-11.59 \mathrm{pm}$ & 0 & 1 & 0 & 0 & 1 & 2 \\
\hline Total & 22 & 156 & 32 & 5 & 4 & 219 \\
\hline \multicolumn{7}{|c|}{ CHI SQUARE TEST RESULT } \\
\hline \multicolumn{3}{|c|}{ CALCULATED VALUE } & \multicolumn{3}{|c|}{ TABLE VALUE } & D.F \\
\hline \multicolumn{3}{|c|}{32.732} & \multicolumn{3}{|c|}{15.507} & 8 \\
\hline
\end{tabular}

From the table 9, the calculated value 32.732 is greater than the table value 15.507 at the level of $5 \%$ significance. Hence the null hypothesis is rejected. Thus it can be inferred that there is a significant association between shift timings and job satisfaction.

Hypothesis 9: There is no significant association between working experience and reward system 
Table 10: CrossTabulation and Chi-Square Result of working experience and reward system

\begin{tabular}{|c|c|c|c|c|c|c|}
\hline \multirow[b]{2}{*}{$\begin{array}{l}\text { Working } \\
\text { Experience }\end{array}$} & \multicolumn{5}{|c|}{ Reward System } & \multirow[b]{2}{*}{ Total } \\
\hline & $\begin{array}{l}\text { Highly } \\
\text { Satisfied }\end{array}$ & Satisfied & Neutral & Dissatisfied & \begin{tabular}{|l} 
Highly \\
Dissatisfied
\end{tabular} & \\
\hline Below 1 years & 9 & 16 & 10 & 0 & 0 & 35 \\
\hline $1-5$ years & 6 & 35 & 62 & 18 & 4 & 125 \\
\hline $5-10$ years & 2 & 12 & 23 & 6 & 0 & 43 \\
\hline $10-15$ years & 0 & 2 & 14 & 0 & 0 & 16 \\
\hline Total & 17 & 65 & 109 & 24 & 4 & 219 \\
\hline \multicolumn{7}{|c|}{ CHI SQUARE TEST RESULT } \\
\hline \multicolumn{3}{|c|}{ CALCULATED VALUE } & \multicolumn{3}{|c|}{ TABLE VALUE } & D.F \\
\hline \multicolumn{3}{|l|}{40.665} & \multicolumn{3}{|c|}{21.026} & 12 \\
\hline
\end{tabular}

From the table 10 , the calculated value 40.665 is greater than the table value 21.026 at the level of $5 \%$ significance. Hence the null hypothesis is rejected. Thus it can be inferred that there is a significant association between working experience and reward system.

Hypothesis 10: There is no significant association between age and safety \& healthy working condition

Table 11: ANOVA - Age and Safety \& Healthy working condition

\begin{tabular}{|l|l|l|l|l|l|l|}
\hline \multicolumn{2}{|l|}{ AGE AND SAFETY \& HEALTHY WORKING CONDITION } \\
\hline SOURCE & $\begin{array}{l}\text { SUM OF } \\
\text { SQUARES }\end{array}$ & DF & $\begin{array}{l}\text { MEAN } \\
\text { SQUARE }\end{array}$ & F & SIG. & REMARKS \\
\hline Between Groups & .873 & 2 & .436 & .642 & .527 & ACCEPTED \\
\cline { 1 - 4 } Within Groups & 146.808 & 216 & .680 & & & \\
\cline { 1 - 4 } Total & 147.680 & 218 & & & & \\
\hline
\end{tabular}

Source: Primary Data

From the table 11, it is concluded that there exists no significant difference between age and safety \& healthy working condition.

Hypothesis 11: There is no significant association between Gender and Job Satisfaction

Table 12: ANOVA - Gender and Job Satisfaction

\begin{tabular}{|l|l|l|l|l|l|l|}
\hline \multicolumn{6}{|l|}{ GENDER AND JOB SATISFACTION } \\
\cline { 1 - 3 } SOURCE & $\begin{array}{l}\text { SUM OF } \\
\text { SQUARES }\end{array}$ & DF & $\begin{array}{l}\text { MEAN } \\
\text { SQUARE }\end{array}$ & F & SIG. & REMARKS \\
\hline Between Groups & .929 & 1 & .929 & 1.932 & .166 & ACCEPTED \\
\cline { 1 - 3 } Within Groups & 104.395 & 217 & .481 & & & \\
\hline
\end{tabular}




\begin{tabular}{|l|l|l|l|l|l|l|}
\hline \multicolumn{2}{|l|}{ GENDER AND JOB SATISFACTION } \\
\hline SOURCE & $\begin{array}{l}\text { SUM OF } \\
\text { SQUARES }\end{array}$ & DF & $\begin{array}{l}\text { MEAN } \\
\text { SQUARE }\end{array}$ & F & SIG. & REMARKS \\
\hline Between Groups & .929 & 1 & .929 & 1.932 & .166 & ACCEPTED \\
Within Groups & 104.395 & 217 & .481 & & & \\
\cline { 1 - 4 } Total & 105.324 & 218 & & & & \\
\hline
\end{tabular}

Source: Primary Data

From the table 12, it is concluded that there exists no significant difference between gender and job satisfaction.

Hypothesis 12: There is no significant association between Marital status and Working environment

Table 13: ANOVA - Marital status and Working environment

\begin{tabular}{|l|l|l|l|l|l|l|}
\hline MARITAL STATUS AND WORKING ENVIRONMENT & \multicolumn{3}{l|}{} \\
\hline SOURCE & $\begin{array}{l}\text { SUM } \\
\text { SQUARES }\end{array}$ & DF & $\begin{array}{l}\text { MEAN } \\
\text { SQUARE }\end{array}$ & F & SIG. & REMARKS \\
\hline Between Groups & .810 & 1 & .810 & 1.125 & .290 & ACCEPTED \\
Within Groups & 156.313 & 217 & .720 & & & \\
\cline { 1 - 3 } & 157.123 & 218 & & & & \\
\hline
\end{tabular}

Source: Primary Data

From the table 13, it is concluded that there exists no significant difference between marital status and working environment.

Hypothesis 13: There is no significant association between Educational qualification and training \& development.

Table 14: ANOVA - Educational qualification and training \& development.

\begin{tabular}{|l|l|l|l|l|l|l|}
\hline EDUCATIONAL QUALIFICATION AND TRAINING \& DEVELOPMENT \\
\hline SOURCE & $\begin{array}{l}\text { SUM OF } \\
\text { SQUARES }\end{array}$ & DF & $\begin{array}{l}\text { MEAN } \\
\text { SQUARE }\end{array}$ & F & SIG. & \\
\hline Between Groups & 1.274 & 3 & .425 & .708 & .548 & ACCEPTED \\
\hline Within Groups & 128.891 & 215 & .599 & & & \\
\hline Total & 130.164 & 218 & & & & \\
\hline
\end{tabular}

Source: Primary Data

From the table 14, it is concluded that there exists no significant difference between Educational qualification and training \& development. 
Hypothesis 14: There is no significant association between Present designation and chance of promotion

Table 15: ANOVA - Present designation and chance of promotion.

\begin{tabular}{|c|c|c|c|c|c|c|}
\hline \multicolumn{7}{|c|}{ PRESENT DESIGNATION AND CHANCE OF PROMOTION } \\
\hline SOURCE & $\begin{array}{l}\text { SUM } \\
\text { SQUARES }\end{array}$ & $\mathrm{DF}$ & $\begin{array}{l}\text { MEAN } \\
\text { SQUARE }\end{array}$ & $\mathrm{F}$ & SIG. & REMARKS \\
\hline Between Groups & 6.924 & 5 & 1.385 & 1.831 & .108 & ACCEPTED \\
\hline Within Groups & 161.103 & 213 & .756 & & & \\
\hline Total & 168.027 & 218 & & & & \\
\hline
\end{tabular}

Source: Primary Data

From the table 15, it is concluded that there exists no significant difference between present designation and chance of promotion.

Table 16: Mean Average Score On Constraints Faced By The Employees

\begin{tabular}{|l|l|l|}
\hline FACTORS & MEAN SCORE & RANK \\
\hline Salary and bonus constraints & 3.20 & 3 \\
\hline Constraints related to allowances and other benefits & 3.11 & 6 \\
\hline Working environment constraints & 3.23 & 2 \\
\hline Constraints in timing & 3.19 & 4 \\
\hline Constraints on superior and subordinate relationship & 3.45 & 1 \\
\hline Adequate Recreation Facilities & 3.17 & 5 \\
\hline Adequate break time/Time of interval & 3.11 & 6 \\
\hline
\end{tabular}

Source: Primary Data

From the table 16, the mean average score on mean average score on various constraints faced by the employees is high with respect to Constraints on superior and subordinate relationship and lowest with respect to 'Adequate break time/Time of interval' and 'Constraints related to allowances and other benefits'.

\section{Results}

\subsection{Findings}

\section{- Personal Information}

Among the 219 respondents, $68 \%$ of them are between the age group of 25 to 35 years of age, $94.5 \%$ of them were Male, $52 \%$ of them are unmarried, With respect to their education, $58 \%$ of them are Under Graduate and 32.4\% of them are in Diploma, 7.3\% of them are Post graduate and $2.3 \%$ of them are School level. $46.8 \%$ of them are worker, $27.4 \%$ of the respondents are office staff and $15.5 \%$ of them are supervisor.

\section{- Job Profile of the employees}

Among the 219 respondents, 86.8\% of the respondents earning monthly income 'Above Rs. 20000 '. 80.4\% of the respondents are from production department, $92.7 \%$ of the respondents 
working in shift timings '9.00 AM - 6.00 PM'. 57.1\% of the respondents having '1-5 years' of experience level.

\section{- Level of Factors Influencing the Employer Branding in Hirotec India Pvt Ltd}

\section{Under SALARY COMPENSATION,}

$>$ Majority $55.7 \%$ of the respondents stated 'Agree' with the factor 'adequate salary and fair compensation is given for my work'.

$>$ Majority $47.5 \%$ of the respondents stated 'Agree' with the factor 'the management provides dearness allowance and other benevolent benefits'.

\section{Under SAFETY \&HEALTHY WORKING CONDITION,}

$>$ Majority $51.6 \%$ of the respondents stated 'Agree' with the factor 'the working condition of my job is free from risk of illness and injury'.

$>$ Majority $62.1 \%$ of the respondents stated 'Agree' with the factor 'Safety measures provided by the management'.

\section{Under GROWTH AND DEVELOPMENT,}

$>$ Majority 58.6\% of the respondents stated 'Agree' with the factor 'Opportunity to work on interesting tasks'.

$>$ Majority $55.3 \%$ of the respondents stated 'Agree' with the factor 'Have opportunities at work to learn and grow'.

\section{Under SUPERIOR RELATIONSHIP,}

$>$ Majority $55.3 \%$ of the respondents stated 'Agree'with the factor 'my superior highly motivates me'.

$>$ Majority $57.1 \%$ of the respondents stated 'Agree' with the factor 'my superior is concerned about the welfare activity of the employees'.

\section{Under JOB SATISFACTION,}

$>$ Majority $71.2 \%$ of the respondents stated 'Agree' with the factor 'my work gives me a feeling of accomplishment and pride'.

$>$ Majority $63.9 \%$ of the respondents stated 'Agree' with the factor 'my views and participation are valued'.

- Level of Opinion to Identify the Work Environment and Organizational Management Style in Hirotec India Pvt Ltd

\section{Under PERSONNEL DEVELOPMENT,}

$>$ Majority $67.6 \%$ of the respondents stated 'Agree' with the factor 'Working experience provided by the company improves my ability'.

$>$ Majority $61.2 \%$ of the respondents stated 'Agree' with the factor 'The company provides opportunity for my career development'. 


\section{Under WORKING ENVIRONMENT,}

$>$ Majority $58.4 \%$ of the respondents stated 'Agree' with the factor 'Physical environment in the organization is comfortable'.

$>$ Majority $52.5 \%$ of the respondents stated 'Agree'with the factor 'Working environment facilities services that helps you to do good jobs'.

\section{Under ORGANIZATION CULTURE AND CLIMATE,}

$>$ Majority $57.1 \%$ of the respondents stated 'Agree' with the factor 'Duty and responsibilities are well schedules in our organization'.

$>$ Majority $40.2 \%$ of the respondents stated 'Agree'with the factor 'The management and union has good relation to ensure important decision for the employees'.

\section{Under RELATION AND CO-OPERATION,}

$>$ Majority $69.9 \%$ of the respondents stated 'Agree' with the factor 'Harmonious relationship with colleagues in the workplace'.

$>$ Majority $60.3 \%$ of the respondents stated 'Agree' with the factor 'Good relationship with your superior in the organization.

\section{Under TRAINING AND DEVELOPMENT,}

$>$ Majority $55.3 \%$ of the respondents stated 'Agree'with the factor 'The training programs help employees to achieve the required skill for performing the job efficiently'.

$>$ Majority $56.6 \%$ of the respondents stated 'Agree' with the factor 'Training programs develops the efficiency of the job to control the wastage'.

\section{- Level of Satisfaction of the Employees on Quality of Work Life (QWL)}

\section{Under RATE OF PAY,}

$>$ Majority $47 \%$ of the respondents stated 'Satisfied' with the pay and benefits such as pension, medical housing which cover their expenses and needs.

$>$ Majority $41.6 \%$ of the respondents stated 'Neutral' with the way in which their pay is sufficient reward in relation to their skills and the effort they put in their job.

\section{Under CHANCE OF PROMOTION,}

$>$ Majority $40.2 \%$ of the respondents stated 'Neutral' with the promotion policy adopted in their organization like result/output competency, work experience, seniority and performance.

$>$ Majority $50.2 \%$ of the respondents stated 'Neutral' with the individual recognition from the superior management which evaluates to chance of promotion.

\section{Under WORK GROUP OF FUNCTIONING,}

$>$ Majority $60.3 \%$ of the respondents stated 'Satisfied' with the extent to which members are involved when a decision has to be made and committed to the group and team work.

$>$ Majority $57.5 \%$ of the respondents stated 'Satisfied'with the way planning and coordination of effort is done in the work group. 


\section{Under JOB SECURITY,}

$>$ Majority $63.9 \%$ of the respondents stated 'Satisfied' with the present job.

$>$ Majority $50.7 \%$ of the respondents stated 'Satisfied'with organizational support for continuing employment in future.

\section{Under EQUIPMENT ADEQUACY,}

$>$ Majority $60.3 \%$ of the respondents stated 'Satisfied' with the manner and ease with which equipment is obtainable to make it possible for them to do their job.

$>$ Majority $63.5 \%$ of the respondents stated 'Satisfied' with the way in which equipment is maintained.

\section{Under REWARD SYSTEM,}

$>$ Majority $49.8 \%$ of the respondents stated 'Neutral' with the degree to which the organization's reviewed system allows for members to be recognized and rewarded for good work.

$>$ Majority $42.5 \%$ of the respondents stated 'Neutral' about the recognition given to an individual or group as they are rewarded.

\section{Under OVERALL SATISFACTION,}

$>$ Majority $61.2 \%$ of the respondents stated 'Satisfied' with the experience the quality of their work life in general.

$>$ Majority $62.6 \%$ of the respondents stated 'Satisfied' with the level of satisfaction on quality of work in the organization.

\section{CONSTRAINTS FACED BY THE EMPLOYEES}

- Majority $42 \%$ of the respondents stated 'Neutral' with the Salary \& Bonus Constraints.

- Majority $53.4 \%$ of the respondents stated 'Neutral' with the Constraints related to allowances and other benefits.

- Majority $40.2 \%$ of the respondents stated 'Neutral' with the working environment constraints.

- Majority $32.9 \%$ of the respondents stated 'High' with the constraints in timing.

- Majority $42 \%$ of the respondents stated 'High' with the constraints on superior and subordinate relationship.

- Majority $43.4 \%$ of the respondents stated 'Low' with the adequate recreation facilities.

- Majority $35.2 \%$ of the respondents stated 'Low' with the adequate break time.

\section{CHI SQUARE ANALYSIS}

- There is no significant association between age and compensation.

- There is no significant association between gender and relationship.

- There is no significant association between marital status and personnel development.

- There is a significant association between educational qualification and growth \& development

- There is a significant association between present designation and job security.

- There is a significant association between monthly income and rate of pay 
- There is a significant association between department and work group functioning

- There is a significant association between shift timings and job satisfaction

- There is a significant association between working experience and reward system

\section{ANALYSIS OF VARIANCE}

- There exists no significant difference between age and safety \& healthy working condition.

- There exists no significant difference between gender and job satisfaction.

- There exists no significant difference between marital status and working environment.

- There exists no significant difference between Educational qualification and training \& development.

- There exists no significant difference between present designation and chance of promotion.

\section{MEAN SCORE ANALYSIS}

The mean average score on mean average score on various constraints faced by the employees is high with respect to Constraints on superior and subordinate relationship and lowest with respect to 'Adequate break time/Time of interval' and 'Constraints related to allowances and other benefits'.

\subsection{Suggestions}

The following suggestion are recommended based on the study by the researcher

- It is recommended to the company that proper allocation of work to the employees will help to avoid overtime work and leads to more satisfied work environment.

- Effective management of workload should be thought to the employees working in the service delivery

- It is recommended that the employees of the company should be given incentives like monetary benefits, promotion, etc for the employees whose performance is excellent will help to develop more satisfied workers.

- Grievance redressed system can be improved.

- The company should conduct performance appraisals in regular intervals so that the company can find performances and the non farmers and then the company can take the necessary action

- Effective strategic HR policies and procedure are essential to govern and provide excellence quality work life among employees

- It is recommended that the company should provide on the job training facilities, so that the work will be completed in stipulated time period and the performance of the employees will also improve.

- Appropriate training programs can be conducted to all cadre of employees which will enhance quality of work life 
- It is suggested that the working conditions of employees should be improved by good ventilations, lighting drinking water facilities, hygienic working conditions, will help to improve more quality of work life in the company.

- Emotional intelligence program can be conducted to middle management employees to improve their emotional and mental state.

- Attitude surveys can be collected once in six months to analyze the suggestion of employees.

- It is suggested that the company should provide good recreation facilities like canteens and organize programs for employees make satisfied employees and make the environment in good condition

\subsection{Conclusion}

The present study is an attempt to know about the study on employer branding in Hirotec India Private Limited focused on various objectives such as analyzing the factors influencing the employer branding, work environment and organizational management style, to analyze the level of satisfaction of the employees and analyze the problems faced by the employees in the company. On the basis of the findings of the study, some practicable and viable suggestions are given.

Today, an active employee value proposition and employer brand is a key for increasing upper hand. Increasingly, Indian companies are revolving out to be decisively calculated to use the employer brand to attract and retain talent for the development. The expanding concentrate on upper hand is driving numerous Indian firms to reevaluate their employer brands. The result indicated that the development value in employer branding influenced the employee's turnover intention. The resultant framework is useful in providing a better understanding on how to improve an effective human resource management from an administrative perspective. The findings would make obtainable for the organizations' management to improve their strategic planning to preserve their valuable employees, thus, building the human assets for the organization. It may also support the organizations' management in determining the value of certain HRM practices and expanding them to the solution in reducing employees' turnover intentions.

\subsection{Scope for Further Study}

Future research on the topic of EMPLOYER BRANDING IN HIROTEC INDIA PRIVATE LIMITED should continue to examine various factors related to employee branding adhered by the Hirotec India Private Limited. Due to the time constraint the study has been limited to only 219 respondents in Coimbatore city. Further the research may be carried for a national or zonal level covering 5 to 8 companies.

\section{References}

[1] Nor Adibah Ahmad et al. (2016). Engaging People with Employer Branding. Elsevier-Procedia Economics and Financ. 86 (1), 690-698. 
[2] Mohamed Wahba et al. (2015). EMPLOYER BRANDING IMPACT ON EMPLOYEE BEHAVIOR AND ATTITUDES APPLIED STUDY ON PHARMATECUAL IN EGYPT. International Journal of Management and Sustainability. 4 (6), 145-162.

[3] Shazia Khalid and Shahnila Tariq. (2015). IMPACT OF EMPLOYER BRAND ON SELECTION AND RECRUITMENT PROCESS. Pakistan Economic and Social Review. 53 (2), 351-372.

[4] Summer Aslam. (June 2015). Potential Employee Segmentation: Employer Branding and Intention to Apply for a Job in Banking Sector, Pakistan. International Journal of Management Sciences and Business Research. 4 (6), 111-116.

[5] Varsha Rokade. (Jan 2015). CONCEPTUALIZING AND RESEARCHING THE MODELS OF EMPLOYER BRANDING. Australian Journal of Business and Management Research . 4 (9), 1421.

[6] Avinash Pawar et al. (Dec 2015). EMPLOYEE VALUE PROPOSITION LEADING TO EMPLOYER BRAND: THE INDIAN ORGANIZATIONS OUTLOOK. International Journal of Management Research \& Review. 5 (12), 1195-1203.

[7] Deepti Verma . (April 2015). A STUDY ON ATTRACTIVENESS DIMENSIONS OF EMPLOYER BRANDING IN TECHNICAL EDUCATIONAL INSTITUTIONS. International Journal of Marketing and Human Resource Management. 6 (1), 36-43.

[8] Howard Adler. (Jan, 2015). The Importance of Compensation and Benefits on University Students' Perceptions of Organizations as Potential Employers . Journal of Management and Strategy. 6 (1), ISSN 1923-3965.

[9] Summer Aslam et al. (2015). Gender Perceptions: Employer Branding Through Attractiveness, Job Characteristics and Organizational Attributes. American Journal of Trade and Policy. 2 (3), 116.

[10] Kaur, Prabhjot, Sharma. (June 2015). Using Social Media for Employer Branding and Talent Management: An Experiential Study. IUP Journal of Brand Management. 12 (2), 1-15.

[11] Neha Sharma. (March 2014). EMPLOYER BRANDING. International Journal of Advance Research. 2 (3), 1-11.

[12] Hassan Nazeer(2014) "The Effect of Quality of Work Life (QWL) Programs on Quality of Life (QOL) among Employees at Multinational Companies in Malaysia"International Journal On Management, Vol 4, Issue 7, February 2014, pp 24-34.

[13] Aybegum Gungordu et al.. (2014). AN EMPIRICAL STUDY ON EMPLOYER BRANDING IN THE CONTEXT OF INTERNAL MARKETING .Journal of Management, Marketing and Logistics . 1 (1), ISSN: 2148-6670.

[14] Mukesh Biswas. (2013). Which Employees' Values Matter Most in the Creation of Employer Branding? Journal of Marketing Development and Competitiveness. 7 (1), 93-102.

[15] G NaslSaraji, and H Dargahi(2013)“Quality Of Work Life In Private Health Care Instituitions” Journal of Management ,Vol 3, Issue 2, December 2013, pp 386-397 